\title{
DOCTOR-NURSE PROFESSIONAL RELATIONSHIP AND HEALTH CARE TEAM COMMUNICATION IN THE HOSPITAL SETTING
}

\author{
Shela Sabrina Mutmainnah, Winny Setyonugroho \\ Masters Program in Hospital Management, Universitas Muhammadiyah Yogyakarta.
}

\begin{abstract}
Background: Medical error has been defined as an unintended act or one that does not achieve its intended health outcome. Medical error causes not only monetary loss, but also lost of patient's trust in the healthcare system, low patient satisfaction, and degraded morale among healthcare professionals, who often feel helpless to change the situation. Patient harm from medical error can occur at the individual or system level. Medical error may arise due to poor doctor-nurse professional relationship and poor health care team communication. This study aimed to assess the doctor-nurse professional relationship and health care team communication in the hospital setting.

Subjects and Method: This was a cross sectional study conducted at 8 teaching hospitals under-cooperation with Universitas Muhammadiyah Yogyakarta, including Bantul Hospital, PKU Muhammadiyah Gamping Hospital, Yogyakarta City Hospital, Magelang Hospital, Purworejo Regional Hospital, Salatiga Regional Hospital, Temanggung Regional General Hospital, and Wonosobo Regional Hospital. A sample of 61 medical co-assistants was selected for this study. The study theme was doctor-nurse professional relationship and health care team communication. The data were collected by questionnaire, in-depth interview, and direct observation.

Results: Doctor-nurse professional relationship, communication, and collaboration, in the medical decision process, discussion for the medical decision process, and dissemination of medical information to patients, were still weak. There were 2 hospitals with the lowest rating points of doctor-nurse relationship and medical team communication, namely Purworejo District Hospital and Yogyakarta City Hospital among the six other hospitals.
\end{abstract}

Conclusion: Doctor-nurse professional relationship and the quality of communication between doctors and other health professionals is still poor.

Keywords: doctor-nurse professional relationship, health care team communication, hospital

\section{Correspondence:}

Shela Sabrina Mutmainnah. Masters Program in Hospital Management, Universitas Muhammadiyah Yogyakarta. Jl. Lingkar Selatan, Tamantirto, Kasihan, Bantul, Yogyakarta. Email: sabrinashela@gmail.com. Mobile: 085757576104 